РОЗДРІБНА КНИЖКОВА ТОРГІВЛЯ ЯК ОСОБЛИВИЙ ВИД ПІДПРИЄМСТВА RETAIL BOOK TRADE AS A SPECIAL TYPE OF ENTERPRISE

УДк 002.2:655.42(477)

https://doi.org/10.32843/infrastruct43-26

\section{Дем'яненко Н.В.}

к.е.н., доцент,

доцент кафедри підприємництва і права

Полтавська державна аграрна академія

Галич О.А.

к.е.н., професор,

профессор кафедри публічного управління

та адміністрування

Полтавська державна аграрна академія

Яснолоб І.О.

к.е.н., доцент,

доцент кафедри підприємництва і права

Полтавська державна аграрна академія

Demyanenko Natalia

Poltava State Agrarian Academy

Galich Olexander

Poltava State Agrarian Academy

Jasnolob Ilona

Poltava State Agrarian Academy у статті визначено, що роздрібна книжкова торгівля - че заключна частина сорери товарного обігу, куди оптові підприємства постачають продукцію різних видавництв, що підлягає роздрібному продажу. У такій торгівлі завершується товаропереміщення неперіодичних видань та забезпечується їх повне доведення до споживача. Визначено, що місія книгарні - це задоволення платоспроможного попиту населення у продукції книгарні, сприяння культурному розвитку населення; ціль книгарні - це дослідження фрактичного попиту споживачів та правильне формування асортименту, прибутковість бізнесу, зайняття конкретної ніші, закріплення особистої частки ринку, окупність інвестицій, вкладених у проект. Зазначено, що складником фрінансового плану розвитку книгарні, зокрема у плануванні прибутку і грошових доходів та видатків, будуть розрахунки беззбиткового обсягу виробництва і реалізації продукції. Зазначено, що негативною тенденцією, яка впливає на зниження рентабельності книгарні, є зменшення чисельності випуску книг на особу - для України обсяг становить менше однієї книги.

Ключові слова: книгарня, книжкова торгівля, доходи, видатки, беззбитковий обсяг виробництва.
В статье определено, что розничная книжная торговля - заключительное звено сореры товарного обращения, куда оптовые предприятия поставляют продукцию издательств, которая подлежит розничной продаже. В этой торговле завершается процесс товароперемещения непериодических изданий, обеспечивается их доведения до потребителя. Определено, что миссия магазина - удовлетворение платежеспособного спроса населения в книжной продукции, содействие культурному развитию населения; цель - исследование спроса потребителей, правильное формирование ассортимента, занятие своей ниши, прибыльность деятельности, закрепление собственной доли рынка, окупаемость вложенных инвестиций. Отмечено, что составной частью текущего финансового плана развития магазина, в частности планирования прибыли и денежных доходов и расходов, явля ются расчеты безубыточного объема производства и реализации продукции. Отмечено, что негативной тенденцией, влияющей на снижение рентабельности магазина, является уменьшение объема выпуска книг на душу населения - для Украины он составляет менее одной книги на человека.

Ключевые слова: книжный магазин, книжная торговля, доходы, расходы, безубыточный объем производства.

The article defines that retail book trade is the final link in the sphere of trade, where wholesale companies supply the products of publishers, which are subject to retail sale. In this trade the process of movement of goods of non-periodicals is completed, their delivery to the consumer is provided. It is determined that the mission of the bookstore is to satisfy the effective demand of the population in book products, to promote the cultural development of the population; goal - research of consumer demand, the correct formation of the range, occupation of its niche, profitability, consolidation of its own market share, return on investment. The organizational and legal form of the bookstore is a business entity, an individual. The advantages of this organizational and legal form include: the ability to work on a single tax; the business entity is exempt from paying value added tax; a natural person-entrepreneur does not pay income tax, as well as a number of other taxes paid by legal entities. The shelves of the Litera store contain about 5,000 items of printed products. At the entrance there is a settlement corner, a department of periodicals. A significant part is occupied by shelves with classical and modern fiction (both world and Ukrainian), as well as familiar to each bookstore, but with a much expanded range of detective stories, fiction, "women's" novels and more. There is a shelf with children's literature: books for the youngest and educational publications, guides for schoolchildren. Specialists of various fields and those who are interested in reference books or books on cooking or magic, waiting for the shelves of the fourth rack. It is noted that an integral part of the current financial plan for the development of the bookstore, in particular the planning of profits and cash income and expenses, are the calculations of break-even production and sales. It is noted that the negative trend that affects the decrease in the profitability of the bookstore is: a decrease in the volume of books per capita - for Ukraine is less than one book per person. Pricing: the trade margin on book products will be about 100\%. Target audience: the successful location of the bookstore in the city center and its wide universal range allows you to target all consumer groups.

Key words: bookstore, book trade, income, expenses, break-even volume of production.

Постановка проблеми. Зміни сучасного суспільства привели до перегляду основних теоретичних і практичних положень функціонування книжкової галузі в Україні. Швидке розповсюдження інформаційно-комунікаційних технологій збільшило інтеграцію систем соціальних комунікацій і зумовило зміни в життєдіяльності учасників комунікаційного простору громади.

Аналіз останніх досліджень і публікацій. Серед дослідників роздрібної книжкової торгівлі як особливого виду підприємства варто назвати Н.О. Голошубову, С.В. Курака, А.Ф. Моргуна, В.В. Нікішкіна, В.В. Апопія, І.П. Міщука, В.М. Ребицького, С.І. Рудницького, Ю.М. Хом'яка та інших.

Постановка завдання. Специфріка підприємництва в книжковій сфрері відображає особливості реалізації поліграсрічної продукції. Книга - це результат творчості, яка віддзеркалює суспільні, політичні, культурні, соціальні та наукові реалії епох; також книга $€$ товаром, адже економічне призначення її друку - отримання прибутку після продажу.

Виклад основного матеріалу дослідження. Роздрібна книжкова торгівля - це заключний елемент обігу товару, куди оптові підприємства реалізують продукцію видавництв, яка підлягає продажу в роздріб. У цьому виді торгівлі завершується процес переміщення товарів різних видань, забезпечується доведення продукції до споживача.

Книжковий магазин «Сторінка» - це перший книжковий маркет у м. Миргород Полтавської області (зареєстрований у 2001 р.). Магазин має 
зручне розміщення - розташований в центрі міста на зупинці громадського транспорту, у магазині правильно сорормовано асортимент книжкової продукції, впроваджено прогресивні методи обслуговування, що підвищує рівень задоволення попиту покупців книг і, відповідно, професійний, культурний та ідейний рівень людей.

Організаційно-правовою формою книгарні вибрано суб'єкт підприємницької діяльності «фрізична особа». До переваг такої організаційноправової форми належить можливість працювати на єдиному податку; суб'єкт підприємницької діяльності звільняється від сплати податку на додану вартість; фрізична особа-підприємець не сплачує податок на прибуток, а також низку інших податків, платниками яких є юридичні особи [8, с. 819].

У магазині в куточку споживача наведено: свідоцтво платника єдиного податку, телефони торгового відділу міськвиконкому, свідоцтво про державну реєстрацію суб'єкта підприємницької діяльності - фрізичної особи-підприємця, зазначений телесрон відділу захисту прав споживачів.

На стелажах книжкового магазину «Сторінка» міститься приблизно 5 тисяч найменувань поліграфрічної продукції. Біля входу розташований розрахунковий куточок та відділ видань періодики. Левову частину займають стелажі з класичною та сучасною художньою літературою (зарубіжною й українською), наведено розширений асортимент детективів, франтастики, «жіночих» романів та ін. Оздоблений стелаж із дитячою літературою: книжечки для малечі й освітні видання, довідники для школярів. Для спеціалістів у різних сорерах і для поціновувачів довідково-пізнавальної літератури чи книг із кулінарії або магії наявні стелажі четвертої стійки.

Місія книгарні - задоволення платоспроможного попиту населення у книжковій продукції, сприяння культурному розвитку населення. Ціль - дослідження попиту споживачів, правильне формування асортименту, зайняття своєї ніші, прибутковість діяльності, закріплення власної частки ринку, окупність вкладених інвестицій [5, с. 102].

Ціноутворення роздрібного книготорговельного підприємства включає торговельну націнку на книжкову продукцію, яка становить близько 100\%. Вдале розміщення книгарні в центрі м. Миргород та універсальний широкий асортимент дають змогу орієнтуватися на всі групи споживачів. Постачальником книгарні $є$ гуртовня «Джерела М». Магазин «Сторінка», крім видавничого асортименту, також пропонує ігри, канцелярію та надає послуги із ксерокопіювання. Операційні витрати книгарні наведені в табл. 1.

Отже, загалом у 2020 р. операційні витрати книгарні «Сторінка» становили 287,5 тис. грн, що на 26,3\% більше, ніж у 2016 р. Серед витрат найвища стаття - оплата праці та соціальні відрахування (170,1 тис. грн.), що на 12,5 \% більше, ніж у 2016 р. Товарообіг книгарні у 2020 р. становив 393,6 тис. грн відповідно. Середня вартість однієї книжки становить приблизно 250 грн.

Приміщення має фрасад, забезпечене всіма комунікаціями - великими вітринними вікнами,

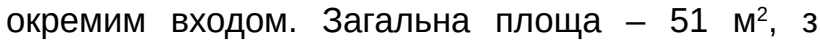

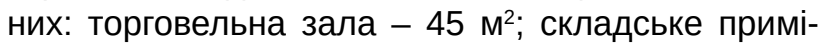
щення - 3 м²; адміністративне приміщення - 3 м². Обладнання книгарні включає: стелажі (8 шт.), прилавок, шафри (4 шт.), стільці (2 шт.), сканер для зчитки штрих-кодів, програмне забезпечення, принтер Epson Expression Home XP, лампи денного освітлення OSRAM. До допоміжного обладнання, призначеного для організації діяльності книгарні, належать засоби малої механізації: транспортери, возики, рахунково-обчислювальна техніка, засоби пожежогасіння тощо [7].

Складовою частиною поточного фінансового плану, зокрема планування прибутку і грошових доходів та видатків, є розрахунки беззбиткового обсягу виробництва і реалізації продукції. Точка беззбитковості $€$ одним із показників, застосовуваних для оцінки ефективності інвестиційних

Таблиця 1

Операційні витрати книгарні «Сторінка», 2016-2020 рр., грн

\begin{tabular}{|c|c|c|c|c|c|c|}
\hline \multirow{2}{*}{ Показники } & \multicolumn{5}{|c|}{ Роки } & \multirow{2}{*}{$\begin{array}{l}2020 \text { р. до } \\
2016 \text { р., \% }\end{array}$} \\
\hline & 2016 & 2017 & 2018 & 2019 & 2020 & \\
\hline $\begin{array}{l}\text { Плата за утримання будинків, } \\
\text { споруд та прибудинкових } \\
\text { територій }\end{array}$ & 1620,0 & 1764,0 & 1800,0 & 2070 & 2430,0 & 150,0 \\
\hline Опалення & 7943,4 & 10379,4 & 10591,2 & 12179,88 & 14298,1 & 180,0 \\
\hline $\begin{array}{l}\text { Водопостачання та } \\
\text { водовідведення }\end{array}$ & 3070,3 & 2710,7 & 2766,0 & 3180,9 & 3734,1 & 121,6 \\
\hline Електроенергія & 39060,0 & 41160,0 & 42000,0 & 48300 & 56700,0 & 145,2 \\
\hline Амортизація & 3576,1 & 4123,1 & 4207,2 & 4838,28 & 5679,7 & 158,8 \\
\hline $\begin{array}{l}\text { Витрати на оплату праці } \\
\text { та соціальні відрахування }\end{array}$ & 151200,0 & 123480,0 & 126000,0 & 144900 & 170100,0 & 112,5 \\
\hline Податки & 21248,0 & 25088,0 & 25600,0 & 29440 & 34560,0 & 162,7 \\
\hline Всього & 227717,8 & 208705,1 & 212964,4 & 244909,1 & 287501,9 & 126,3 \\
\hline
\end{tabular}


проектів [6, с. 400]. Вихідні дані для визначення беззбитковості реалізації книг наведено в табл. 2.

Річний беззбитковий рівень реалізації книг у магазині «Сторінка» становить 436 штук.

Аналіз беззбитковості проекту дає змогу виявити залежність розміру прибутку від визначальних фракторів: обсягу продажів, зміни ціни продукції, цін на сировину тощо. Ця інорормація з урахуванням бажаного інтервалу значень цін продажу, видатків підприємства може використовуватися для оцінки інвестиційного проекту й інвестиційного ризику [4, с. 80]. Грасрік беззбитковості реалізації книг наведено на рис. 1.

За беззбиткового обсягу виробництва і продажу продукції книгарня не отримує ні прибутку, ні збитку, а лише покриває свої витрати. Кожна продана одиниця продукції, що перевищує точку беззбитковості, приносить підприємству прибуток [1, с. 4].

Власниця книгарні «Сторінка» має мету: зробити усе можливе, щоб українська сучасна література мала читача, могла вільно продаватися на книжковому ринку і переважати над

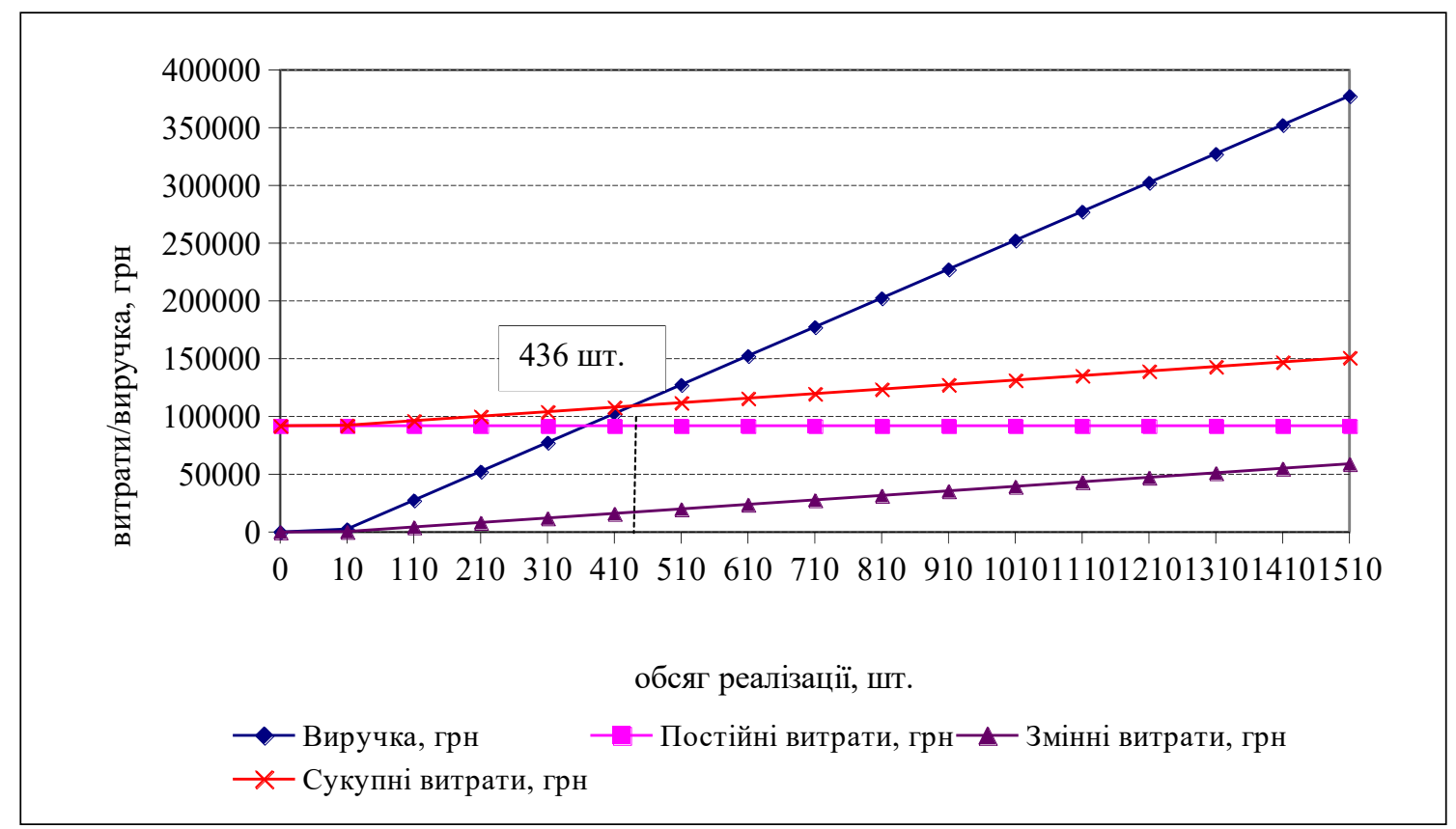

Рис. 1. Беззбитковий обсяг реалізації книг у магазині «Сторінка», 2020 р.

Беззбитковий обсяг реалізації книг у книгарні «Сторінка», 2020 р.

\begin{tabular}{|c|c|c|c|c|c|}
\hline $\begin{array}{c}\text { Обсяг реалізації, } \\
\text { шт. }\end{array}$ & Виручка, грн & $\begin{array}{c}\text { Постійні } \\
\text { витрати, грн }\end{array}$ & $\begin{array}{c}\text { 3мінні витрати, } \\
\text { грн }\end{array}$ & $\begin{array}{c}\text { Сукупні } \\
\text { витрати, грн }\end{array}$ & Прибуток, грн \\
\hline 0 & 0 & 92000,6 & 0 & 92000,6 & $-92000,6$ \\
\hline 10 & 2500,0 & 92000,6 & 391,0 & 92391,6 & $-89891,6$ \\
\hline 110 & 27500,0 & 92000,6 & 4301,0 & 96301,6 & $-68801,6$ \\
\hline 210 & 52500,0 & 92000,6 & 8211,1 & 100211,7 & $-47711,7$ \\
\hline 310 & 77500,0 & 92000,6 & 12121,1 & 104121,7 & $-26621,7$ \\
\hline 410 & 102500,0 & 92000,6 & 16031,1 & 108031,7 & $-5531,7$ \\
\hline 436 & 109000,0 & 92000,6 & 17047,7 & 109000,0 & 0,0 \\
\hline 510 & 127500,0 & 92000,6 & 19941,1 & 111941,7 & 15558,3 \\
\hline 610 & 152500,0 & 92000,6 & 23851,1 & 115851,7 & 36648,3 \\
\hline 710 & 177500,0 & 92000,6 & 27761,2 & 119761,8 & 57738,2 \\
\hline 810 & 202500,0 & 92000,6 & 31671,2 & 123671,8 & 78828,2 \\
\hline 910 & 227500,0 & 92000,6 & 35581,2 & 127581,8 & 99918,2 \\
\hline 1010 & 252500,0 & 92000,6 & 39491,2 & 131491,8 & 121008,2 \\
\hline 1110 & 277500,0 & 92000,6 & 43401,3 & 135401,9 & 142098,1 \\
\hline 1210 & 302500,0 & 92000,6 & 47311,3 & 139311,9 & 163188,1 \\
\hline 1310 & 327500,0 & 92000,6 & 51221,3 & 143221,9 & 184278,1 \\
\hline 1410 & 352500,0 & 92000,6 & 55131,3 & 147131,9 & 205368,1 \\
\hline 1510 & 377500,0 & 92000,6 & 59041,4 & 151042,0 & 226458,0 \\
\hline
\end{tabular}


кількістю зарубіжних видань. Співпрацює книгарня з 15 видавництвами України та близького зарубіжжя. Магазин «Сторінка» підтримує українські видавництва та літературу. Серед усіх надходжень 87\% - це україномовні видання з різних галузей знань.

Ефективність підприємницької діяльності книгарні наведено в табл. 3.

Загалом середня ціна книги у 2020 р. зросла до 250 грн./шт., що в 2,6 раза більше, ніж у 2016 р. Виробничі витрати становили 287,5 тис. грн., що на 26,3\% більше, ніж у 2016 р., в тому числі постійні витрати становили 32\% - 92 тис. грн., а змінні 68\% - 195,5 тис. грн. Валовий дохід від реалізації продукції зріс до 569,3 тис. грн., що на 19\% більше, ніж у 2016 р. У тому числі від реалізації книг фрізична-особа підприємець отримала валового доходу на суму 466,8 тис. грн., від реалізації канцелярської продукції - 102,5 тис. грн., від продажу дитячих ігор - 10,5 тис. грн. Рівень рентабельності реалізації продукції магазином «Сторінка» у 2020 р. зменшився до 98\%, що на 12\% менше, ніж у 2016 р. Економічна ситуація в країні загалом впливає на успішність діяльності книгарні, якщо розглядаючи їі з погляду зміни рівня доходу, купівельної спроможності населення. Негативними явищами $€$ зростання інфрляції, внаслідок чого купівельна спроможність населення зменшується.

Негативною тенденцією, що впливає на зниження рентабельності книгарні, $€$ зменшення обсягу випуску книжок на душу населення - для України він становить менше однієї книги на особу (тоді як за часів Радянського Союзу цей показник становив 7-10 книг на особу). За результатами дослідження Research \& Branding Group, 50,9\% опитаних українців не читають книжок, 48,7\% читають, 0,4\% опитаних не змогли відповісти [7].

Середній вік населення жителів м. Миргород у 2019 р. становив 42,8 років, що $є$ прийнятним значенням - згідно з маркетинговими дослідженнями, середній вік людей, що купують книжки, становить 35-40 років. Розміщення книгарні у м. Миргород є беззаперечним плюсом, адже у місті зосереджена значна кількість курортів.

Інновацій у галузі, окрім онлайн-магазинів книжок, немає. Проте такий спосіб книготоргівлі $€$ серйозним конкурентом стаціонарних книгарень, адже відсутність орендної плати за приміщення книгарні зменшує торгову націнку на книжку, тим самим підвищуючи власну конкурентоспроможність [3].

Конкуренція у ринковій економіці - це суперництво, боротьба між виробниками товарів та послуг за кращі, економічно вигідні умови виробництва та реалізації продукту [2, с. 78]. Основними конкурентами магазину «Сторінка» $€$ книжковий магазин в ТРЦ «Мир» та «Фуршет». Дискретність і слабкість книготорговельної мережі в м. Миргород компенсується за рахунок базарів, кіосків та розкладок.

Визначимо переваги та недоліки у сорері продажу книг у табл. 4.

Перешкоджати успішній діяльності книгарні може те, що книга не є товаром першої необхідності, вона не характеризується швидким оборотом; необхідність закупівлі товару за передоплатою та складність повернення товару; малий відсоток людей, що читають книжки (за даними дослідження, із загальної кількості читачів 29,8\% читають кілька разів на місяць, 26,5\% - кілька разів на тиждень, 17,7\% - майже щодня, 21,5\% читають кілька разів на рік та 2,3\% - рідше, ніж раз на рік). Сприяє ефрективній діяльності книгарні широкий асортимент (за даними дослідження, 36,3\% респондентів читають історичні твори, 34,3\% детективи, 26,2\% - віддають перевагу любовним романам; високий попит на дитячу літературу); надання переваги традиційній фрормі книги $(86,7 \%$ респондентів відповіли, що люблять читати книги

Таблиця 3

Ефективність підприємницької діяльності книгарні «Сторінка», 2016-2020 рр., грн

\begin{tabular}{|l|c|c|c|c|c|c|}
\hline \multicolumn{1}{|c|}{ Показники } & \multicolumn{9}{c|}{ Роки } & $\begin{array}{c}\mathbf{2 0 2 0} \text { р. до } \\
\mathbf{2 0 1 6} \text { р., \% }\end{array}$ \\
\cline { 2 - 7 } & $\mathbf{2 0 1 6}$ & $\mathbf{2 0 1 7}$ & $\mathbf{2 0 1 8}$ & $\mathbf{2 0 1 9}$ & $\mathbf{2 0 2 0}$ & в 2,6 p. б. \\
\hline Середня ціна книги, грн & 95,0 & 102,0 & 108,0 & 195,0 & 250,0 & 126,3 \\
\hline Виробничі витрати - всього, грн & 227717,8 & 208705,1 & 212964,4 & 244909,1 & 287501,9 & 134,7 \\
\hline в. т. ч. постійні витрати, грн & 68315,3 & 62611,5 & 63889,3 & 73472,7 & 92000,6 & 122,6 \\
\hline змінні витрати, грн & 159402,5 & 146093,6 & 149075,1 & 171436,4 & 195501,3 & 119,0 \\
\hline $\begin{array}{l}\text { Валовий дохід від реалізації - } \\
\text { всього, грн }\end{array}$ & 478207,4 & 361059,8 & 417410,2 & 457980,0 & 569253,8 & 114,8 \\
\hline в. т. ч. від реалізації книг & 406476,3 & 306900,8 & 354798,7 & 389283,0 & 466788,1 & 166,7 \\
\hline канцелярської продукції & 61480,8 & 54159,0 & 62611,5 & 68697,0 & 102465,7 & 102,8 \\
\hline ігор & 10250,3 & 10500,3 & 10430,3 & 10375,3 & 10535,3 & 112,5 \\
\hline Прибуток, грн & 250489,6 & 152354,7 & 204445,8 & 213070,9 & 281751,9 & 112,5 \\
\hline $\begin{array}{l}\text { Беззбитковий обсяг реалізації } \\
\text { книг, шт. }\end{array}$ & 386 & 398 & 385 & 440 & 436 & 113,0 \\
\hline Рівень рентабельності, \% & 110,0 & 73,0 & 96,0 & 87,0 & 98,0 & х \\
\hline
\end{tabular}


Переваги та недоліки роботи книгарні «Сторінка», 2020 р.

\begin{tabular}{|c|c|c|}
\hline & Можливості & Загрози \\
\hline 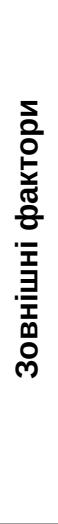 & $\begin{array}{l}\text { Сприятлива податкова політика } \\
\text { для книгарень з україномовним } \\
\text { асортиментом; } \\
\text { спрощена система подання звітності } \\
\text { книгарнею як суб'єкта підприємницької } \\
\text { діяльності; } \\
\text { зручне розташування у центрі міста } \\
\text { Миргород; } \\
\text { великий потік відвідувачів; } \\
\text { сприятлива атмосфрера книгарні, } \\
\text { кваліфікований персонал; } \\
\text { широкий асортимент книжкової } \\
\text { продукції, орієнтовний на усі читацькі } \\
\text { групи; } \\
\text { активна рекламна діяльність. }\end{array}$ & $\begin{array}{l}\text { Широкий вибір проведення дозвілля іншим шляхом, аніж } \\
\text { читання; } \\
\text { розповсюдженість електронних засобів читання; } \\
\text { безоплатність отримання книжок в електронному форматі; } \\
\text { малий відсоток людей, що читають книжки } \\
\text { (50,9 \% за дослідженням Research \& Branding Group); } \\
\text { існування інтернет-магазинів книжок із нижчою торговою } \\
\text { націнкою; } \\
\text { достатня кількість конкурентів за територіальною ознакою; } \\
\text { інфляційні процеси та зниження купівельної спроможності серед } \\
\text { населення; } \\
\text { невисокий рівень доходу населення; } \\
\text { повільна оборотність книжки як товару; } \\
\text { обмеження річного обороту книгарні як суб'єкта підприємницької } \\
\text { діяльності у 500 тис. грн. }\end{array}$ \\
\hline
\end{tabular}

у традиційній фрормі, 10,4\% - користуються гаджетами, електронними книгами, а 2,1\% вибирають аудіокниги); зручне розміщення магазину в місті у місці великого скупчення людей, у тому числі туристів; переваги організаційно-правової форми книгарні, а саме подання звітності раз у квартал, звільнення від низки податків та платежів, які сплачують юридичні особи, плата єдиного податку [7].

Висновки 3 проведеного дослідження. Магазин «Сторінка» створено в лютому 2001 р. 3 метою забезпечення суспільних потреб територіальної громади м. Миргород, установ та організацій книжковою, навчальною, іншою друкованою продукцією, шкільно-письмовими, канцелярськими та іншими товарами. Мета книгарні - зробити українську книгу доступним інтелектуальним надбанням українців. Книгарня співпрацює з багатьма видавництвами України, а також близького зарубіжжя. Серед усіх надходжень 85 \% - україномовні видання в різних сорерах господарювання. Асортимент книгарні «Сторінка» постійно поповнюється новинками книжкового ринку, що вказує на оперативність та фраховість продавців та товарознавця-власниці.

\section{БІБЛІОГРАФІЧНИЙ СПИСОК:}

1. Головачко Н. Львівська «Буква» надаватиме перевагу українській літературі. Високий замок. 2004. № 42. C. 4.

2. Голошубова Н.О. Організація торгівлі : підручник. К. : Книга, 2004. 560 с.

3. Курамка А. Методы анализа ассортиментного портфеля предприятия URL : http://www.iteam.ru/ publications/marketing.article_2963 (дата звернення: 12.05.2020).

4. Марченко О.І. Асортимент продукції підприємства як важливий фактор зростання прибутку. Формування ринкових відносин в Україні. 2019. № 8 (63). C. 78-92.

5. Мусаткіна В.П. Вплив маркетингової політики на продуктивність торговельного підприємства. Науко- вий вісник Мукачівського державного університету. Серія «Економіка». 2016. вип. 1 (1). С. 101-104.

6. Панченко А.В. Теоретичні аспекти управління якістю торговельного обслуговування на засадах системного підходу. Наукові праці КНТУ. Економічні науки. Випуск 15, 2009. С. 399-407.

7. Особливості підприємництва в книжковій торгівлі. URL: http://um.co.ua/3/3-14/3-141631.html (дата звернення: 02.05.2020).

8. Щербак В.Г., Перебийнос Р.В. Формування й реалізація стратегії управління асортиментною політикою підприємства. Економіка: проблеми теорії та практики, 2017. Вип. 208, т. 3. С. 817-826.

\section{REFERENCES:}

1. Holovachko, N. (2004), "Lviv's Bukva will give preference to Ukrainian literature", Vysokyi zamok, vol. 42, pp. 4.

2. Goloshubova, N. (2004), Organizaciya torgivli [Organization of trade], knyga, Kyiv, Ukraine.

3. Marchenko, O. (2019), "The range of products of the enterprise as an important factor in profit growth", Formuvannia rynkovykh vidnosyn v Ukraini, vol. 8 (63), pp. 78-92.

4. Kuramka, A. "Methods of analysis of the assortment portfolio of the enterprise", available at: http://www.iteam.ru/publications/marketing.article_2963 (Accessed 12 May 2019).

5. Musatkina V. (2016), "The impact of marketing policy on the productivity of the trading company". Naukovyi visnyk Mukachivskoho derzhavnoho universytetu, vol. 1, pp. 101-104.

6. Panchenko A. (2009), "Theoretical aspects of quality management of trade services on the basis of a systematic approach", Naukovi pratsi KNTU, vol. 15, pp. 399-407.

7. "Features of entrepreneurship in the book trade", available at: http://um.co.ua/3/3-14/3-141631.html (Accessed 12 May 2019).

8. Shcherbak V. and Perebyinos R. (2017), "Formation and implementation of the strategy of assortment policy of the enterprise". Ekonomika: problemy teorii ta praktyky, vol. 208, no. 3, pp. 817-826. 